\title{
Ułomności statystyki motoryzacji w Polsce i ich konsekwencje dla badań geograficznych \\ Shortcomings of Poland's motorisation statistics, and their implications for geographical research
}

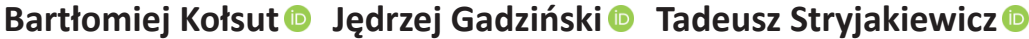 \\ Uniwersytet im. Adama Mickiewicza w Poznaniu \\ Wydział Geografii Społeczno-Ekonomicznej i Gospodarki Przestrzennej \\ ul. Bogumiła Krygowskiego 10, 61-680 Poznań \\ bartkol@amu.edu.pl•jedgad@amu.edu.pl•tadek@amu.edu.pl
}

Zarys treści. Celem artykułu jest identyfikacja ułomności statystyki opisującej wielkość i strukturę parku samochodów osobowych w Polsce, a także sformułowanie konsekwencji tych ułomności dla badań geograficznych. Ułomności, które poddano szczegółowej analizie, podzielono na trzy grupy: 1) „martwe dusze”, czyli zawyżanie liczby pojazdów poprzez pozostawanie w ewidencji samochodów od dawna nieporuszających się po drogach, 2) „auta z kratką”, czyli zaniżanie liczby samochodów osobowych i zawyżanie liczby samochodów ciężarowych w związku z masowym zjawiskiem rejestrowania aut osobowych z homologacją ciężarową oraz 3) auta firmowe, czyli zawyżanie liczby pojazdów w miastach będących siedzibami firm leasingowych i dużych przedsiębiorstw posiadających samochody służbowe. W artykule określono skalę przeszacowania wielkości wskaźnika motoryzacji w Polsce, a także obszary (traktując powiaty jako podstawowe jednostki przestrzenne), na których to przeszacowanie przyjmuje najwyższe wartości.

Słowa kluczowe: statystyka motoryzacji, poziom motoryzacji, rynek samochodów, geografia transportu, Polska. Keywords: motorisation statistics, car ownership, car market, transport geography, Poland.

\section{Wstęp}

Publikowane corocznie raporty Komisji Europejskiej (np. European Commission, 2018) od wielu lat pokazują relatywnie bardzo wysoki poziom motoryzacji w Polsce. Według danych z 2016 r. Polska była szóstym najbardziej zmotoryzowanym państwem Unii Europejskiej (571 samochodów osobowych na 1000 mieszkańców). Była to zdecydowanie najwyższa wartość wśród państw postsocjalistycznych, które wstąpiły do UE po 2004 r. Wskaźnik motoryzacji w Polsce osiągnął - w stosunku do innych wskaźników rozwoju społeczno-gospodarczego, a także w porównaniu z innymi krajami - ponadprzeciętnie wysoki poziom, co pociągało za sobą konkretne rekomendacje w zakresie polityki transportowej. Również badania międzynarodowe dotyczące czynników zmian w poziomie motoryzacji pokazywały wyraźnie niestandardowy przebieg tego procesu w naszym kraju. W jednym z najczęściej cytowanych artykułów motoryzacyjnych (Dargay i inni, 2007), w którym autorzy porównali zmiany poziomu motoryzacji i dochodu narodowego per capita w 45 państwach w okresie 1960-2002, sytuacja w Polsce wyraźnie odstawała od relacji tych dwóch 
zmiennych w pozostałych państwach. Był to jednostkowy wyjątek w całym zbiorze (a analizie poddano także dużą grupę państw rozwijających się). Analiza zmian poziomu motoryzacji i poziomu dochodu w Polsce w tym okresie pokazała ponad dwukrotnie wyższy od większości państw europejskich poziom elastyczności dochodowej popytu na samochody. Ma to z pewnością związek ze ścieżką rozwojową na jaką weszła Polska po 1989 r., ale przynajmniej równie ważnym czynnikiem kształtującym taki obraz procesu (jeśli nie ważniejszym) jest jakość polskich danych motoryzacyjnych wykorzystywanych do badań i porównań międzynarodowych, które zawyżają wartości wskaźnika motoryzacji.

Od wielu lat opracowania dotyczące branży motoryzacyjnej wskazują (zob. np. Kublik, 2005, 2013a, 2013b), że oficjalne dane na temat liczby samochodów osobowych nie odzwierciedlają rzeczywistego stanu tego zjawiska. Problem ten jest dość dobrze znany w środowisku praktyków i ekspertów motoryzacyjnych (był także analizowany przez Instytut Badań Rynku Motoryzacyjnego SAMAR), jednak nie był on dotąd, poza nielicznymi przypadkami (np. Komornicki, 2008, 2011; Menes, 2018), wprowadzany do dyskusji naukowej na temat motoryzacji. Niniejszy artykuł próbuje wypełnić tę lukę.

Celem artykułu jest identyfikacja ułomności statystyki opisującej wielkość i strukturę parku samochodów osobowych w Polsce, a także sformułowanie konsekwencji tych ułomności dla badań geograficznych. Realizację tak sformułowanego celu umożliwia pojawienie się nowego, coraz bardziej wiarygodnego źródła informacji, tzn. centralnej ewidencji pojazdów (CEP) 2.0, w której zgromadzono szczegółowe dane opisujące pojazdy samochodowe w Polsce. Tego typu dane są wykorzystywane do analiz motoryzacyjnych, w tym w przekroju regionalnym (np. Lansley, 2016).

Analizę, prezentowaną w dalszej części artykułu, przeprowadzono na podstawie danych pozyskanych z CEP, dotyczących wybranych charakterystyk samochodów osobowych (rok pierwszej rejestracji w Polsce, rok produkcji, dopuszczalna ładowność, liczba miejsc, stan pojazdu) oraz ich właścicieli (powiat zamieszkania lub prowadzenia działalności gospodarczej, nr REGON). Zostały one przetworzone i zaprezentowane z wykorzystaniem kilku metod analizy statystycznej i przestrzennej, w tym wskaźników struktury zjawisk, metod kartograficznych oraz analizy korelacji między segmentami pojazdów a wybranymi cechami społeczno-gospodarczymi.

Artykuł składa się z czterech części. W pierwszej z nich przedstawiamy najważniejsze ułomności statystyki motoryzacji w Polsce wyróżnione na podstawie studiów literaturowych. Następnie opisujemy sposób gromadzenia danych i prowadzenia ewidencji statystyki motoryzacji w Polsce. Przedmiotem trzeciej części artykułu jest pogłębiona analiza danych CEP, które pozwalają szacować wielkość i strukturę wybranych ułomności statystyki motoryzacyjnej. Na koniec podejmujemy próbę określenia konsekwencji tych ułomności dla badań geograficznych.

\section{Główne ułomności statystyki motoryzacji w Polsce}

Dane dotyczące motoryzacji były dotąd wykorzystywane do badania szeregu zjawisk i procesów społeczno-gospodarczych. W znacznej większości z nich źródło informacji o liczbie samochodów osobowych w Polsce stanowiły bazy danych Głównego Urząd Statystycznego (GUS). Były one przyjmowane raczej dość bezkrytycznie (poza nielicznymi wyjątkami), a ich ułomności pozostawały przedmiotem dyskusji podczas konferencji i spotkań branżo- 
wych, rzadziej stając się przedmiotem analiz w publikacjach naukowych. Udostępnienie zasobów CEP stwarza nowe możliwości analizy i pozwala szacować wielkość i strukturę błędów wykorzystywanych danych. Wydaje się, że analizując najczęściej występujące informacje na temat mierników poziomu motoryzacji w polskiej statystyce publicznej należy skupić się na sześciu głównych ułomnościach.

1. „Martwe dusze”, czyli zawyżanie liczby pojazdów poprzez pozostawanie w ewidencji samochodów od dawna nieporuszających się po drogach. Według dotychczasowych przypuszczeń zjawisko to obecne jest szczególnie na tzw. obszarach popegeerowskich. Szacowane one były pośrednio przez T. Komornickiego (2006, 2011) na podstawie odsetka pojazdów starszych niż 30 lat, których przestrzenną koncentrację obserwowano głównie na Pomorzu Zachodnim, Ziemi Lubuskiej oraz w dawnych województwach: wałbrzyskim, wrocławskim i opolskim (udział pojazdów starszych niż 30 lat wynosił tam więcej niż 10\%). Z kolei w prasie branżowej jako główną przyczynę obecności „martwych dusz” w ewidencji podaje się przede wszystkim szarą strefę w sektorze demontażu i złomowania pojazdów. Właściciel pojazdu oddając go do „zwykłego” punktu złomowania (tzn. nieprzystosowanego do składowania oraz demontażu zużytych samochodów i ich recyklingu) jest w stanie zyskać większą kwotę rekompensaty, a ryzyko, które ponosi jest stosunkowo niewielkie (brak sankcji za złomowanie pojazdów w szarej strefie). Szacunki firm zajmujących się recyklingiem aut pokazują, że ok. 80\% samochodów w Polsce jest złomowanych w szarej strefie, co skutkuje ich niewyrejestrowywaniem (Kublik, 2013b). Problem „martwych dusz” powoduje zaniżanie liczby samochodów osobowych w każdej polskiej gminie, a dla geografii szczególnie interesujący jest rozkład przestrzenny tego zjawiska (co zostanie przedstawione w dalszej części artykułu).

2. „Auta z kratką”, czyli zaniżanie liczby samochodów osobowych i zawyżanie liczby samochodów ciężarowych w związku z masowym zjawiskiem rejestrowania aut osobowych z homologacją ciężarową. Problem ten, szacowany w 2003 r. na ok. 15,2\% wszystkich pojazdów osobowych w Polsce (Komornicki, 2006, s. 130, 2011, s. 40), w zwiększonym natężeniu (wg tych szacunków) występuje w aglomeracjach miejskich Warszawy, Poznania, Krakowa i Gdańska, na terenach sadowniczych powiatów grójeckiego i sandomierskiego oraz na Podhalu. „Auta z kratką” to zjawisko wynikające z możliwości odliczania od podatku dochodowego części kosztów zakupu i użytkowania pojazdów przez przedsiębiorstwa, przy czym trzeba dodać, że aktualnie możliwości odliczeń w tym zakresie są stosunkowo niewielkie, co z pewnością wpływa na skalę odnotowywanych ułomności oficjalnej statystyki.

3. Auta firmowe, czyli zawyżanie liczby pojazdów w miastach będących siedzibami firm leasingowych i dużych przedsiębiorstw posiadających samochody służbowe. Zjawisko to związane jest z oddzieleniem siedziby właściciela pojazdu od lokalizacji zamieszkania jego użytkownika. W świetle dotychczasowych badań był to problem zaznaczający się szczególnie w Warszawie i Poznaniu (Komornicki, 2006, s. 130, 2011, s. 43). Nasilenie tego zjawiska jest następstwem przede wszystkim rozwoju firm leasingowych, z kolei rozwój tego rynku wiąże się z możliwościami odliczania kosztów wynajmu od osiąganych dochodów. Problem aut firmowych nie wpływa na ogólną liczbę samochodów osobowych w Polsce, związany jest jednak z rozkładem przestrzennym ich użytkowania (zawyżając liczbę pojazdów w dużych miastach i zaniżając w innych gminach). 
4. Auta migrantów wewnętrznych, czyli zaniżanie liczby samochodów osobowych w największych aglomeracjach miejskich, jako pochodna nieodnotowywanych migracji wewnętrznych. Problem ten związany jest ze zmianą miejsca zamieszkania ludności bez przerejestrowywania pojazdu (m.in. w związku z wyższymi stawkami ubezpieczenia OC wyliczanymi przez firmy ubezpieczeniowe dla pojazdów poruszających się w dużych aglomeracjach). Nie był on dotąd analizowany w publikacjach naukowych (choć wspomina o nim T. Komornicki, 2011) i w zasadzie jest nieobecny w prasie branżowej.

5. „Auta polsko-ukraińskie”, czyli zawyżanie liczby pojazdów poprzez masowe rejestrowanie samochodów jeżdżących na terenie Ukrainy przez polskich współwłaścicieli. Problem ten wiąże się z wysokimi cłami na samochody używane obowiązującymi na terenie Ukrainy. Wysokie cła spowodowały upowszechnienie się zjawiska "handlu” współwłasnością oferowaną przez Polaków mieszkających przy granicy z Ukrainą. Problem ten nie był dotąd przedmiotem analiz naukowych, pojawiał się wyłącznie w prasie codziennej i branżowej. Jest to zjawisko, które przeszacowuje liczbę samochodów osobowych w gminach zlokalizowanych przy granicy z Ukrainą i dodatkowo wpływa na zawyżanie wskaźnika motoryzacji w całej Polsce. Problem aut polsko-ukraińskich ma także konsekwencje innego rodzaju, tzn. zwiększa kolejki na przejściach granicznych w związku z obowiązkiem obecności samochodu zarejestrowanego w Polsce przynajmniej raz na pięć dni w naszym kraju (w praktyce oznacza to, że prawie wszyscy Ukraińcy posiadający polsko-ukraiński samochód co kilka dni przekraczają granicę z Polską).

6. Używane auta sprowadzone przez importerów komercyjnych, czyli zawyżanie liczby pojazdów na obszarach dużej koncentracji firm importujących samochody osobowe w celach handlowych. Znaczna część importu samochodów używanych odbywa się poprzez wyspecjalizowane w tym zakresie firmy, a część pojazdów (mimo niewykorzystywania ich w celach transportowych) zostaje także przez nich zarejestrowana (co ma związek z obowiązującymi przepisami prawa). Fakt ten zawyża liczbę samochodów osobowych w przynajmniej kilkunastu powiatach, głównie w Wielkopolsce i na Ziemi Lubuskiej. Zagadnienie to jest dość trudne do precyzyjnego szacowania i nie było dotąd analizowane w publikacjach naukowych.

Przedstawione ułomności oraz ich przyczyny zaprezentowano - wraz z określeniem charakteru ich wpływu na liczbę samochodów osobowych zaewidencjonowanych w danej jednostce terytorialnej (np. gminie) - na rycinie 1.

Wszystkie zidentyfikowane ułomności statystyki motoryzacji mają istotny wpływ na prowadzone badania i rodzaj powstającej w ich toku wiedzy. Niestety, nawet CEP nie daje możliwości pełnego rozpoznania skali i struktury wszystkich z nich. Pierwsze trzy (tzn. „martwe dusze”, „auta z kratką" oraz auta firmowe) będą stanowiły przedmiot szczegółowej analizy w niniejszym artykule. Trzy pozostałe ułomności są znacznie trudniejsze do pogłębionej analizy, wymagają bowiem zastosowania innych technik badawczych. Szacowanie skali zaniżania liczby samochodów osobowych w dużych aglomeracjach, w związku z migracjami i nieprzerejestrowywaniem pojazdów przez ich właścicieli, może być wykonane poprzez zastosowanie techniki obserwacji pośredniej (np. wylosowanie reprezentatywnej próby osiedli w dużych miastach i wykonanie systematycznej i powtarzalnej inwentaryzacji tablic rejestracyjnych pojazdów na tych osiedlach). Jest to jednak zadanie dość czasochłonne i wymagające dużych zespołów badawczych. Z kolei skala problemu 


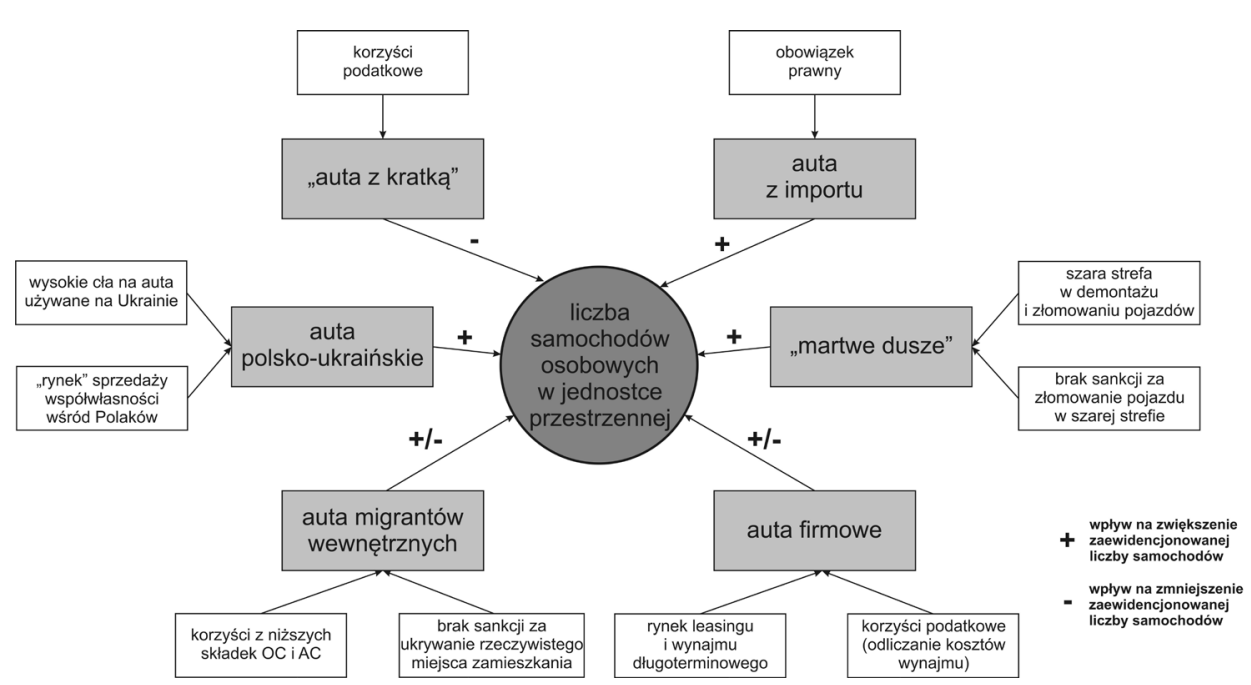

Ryc. 1. Schemat wpływu ułomności statystyki motoryzacji i ich przyczyn na liczbę samochodów osobowych zaewidencjonowanych w danej jednostce terytorialnej Impact of the defects in motorisation statistics and their causes on the number of personal cars registered in a given territorial unit

aut polsko-ukraińskich i problemu aut z importu jest bardzo trudna do oszacowania (a niekiedy nawet niemożliwa) i wymaga wykorzystania danych, które nie są publikowane lub udostępniane w CEP.

\section{Centralna ewidencja pojazdów - historia tworzenia i wartość informacyjna}

Jak już wcześniej wspomnieliśmy, polskie badania motoryzacyjne opierały się dotąd przede wszystkim na danych publikowanych przez GUS. Są to informacje dotyczące pojazdów (w tym samochodów osobowych), udostępniane według stanu w dniu 31 grudnia każdego roku. Informacje te były pozyskiwane z różnych źródeł (tab. 1). Do 2001 r. były to ewidencje prowadzone przez wojewodów, nazywane wojewódzkimi ewidencjami po-

Tabela 1. Podmioty odpowiedzialne za gromadzenie i udostępnianie statystyki motoryzacji w Polsce Authorities responsible for the collection and supply of motorisation statistics in Poland

\begin{tabular}{|l|l|l|l|}
\hline \multicolumn{1}{|c|}{ Okres } & Miejsce rejestracji pojazdów & \multicolumn{1}{|c|}{ Ewidencje pojazdów } & \multicolumn{1}{c|}{ Źródło danych GUS } \\
\hline do 1990 r. & urząd gminy & wojewódzkie (49) & WEP \\
1990-1998 & urząd rejonowy & wojewódzkie (49) & WEP \\
1999-2001 & starostwo powiatowe & wojewódzkie (16) & WEP \\
2002-2003 & starostwo powiatowe & wojewódzkie (16) & bazy powiatowe \\
$2004-2008$ & starostwo powiatowe & centralna (1.0) & bazy powiatowe \\
$2008-2017$ & starostwo powiatowe & centralna (1.0) & CEP \\
od 11.2017 & starostwo powiatowe & centralna (2.0) & CEP \\
\hline
\end{tabular}


jazdów (WEP), do których dane przesyłały organy rejestrujące pojazdy (do 1990 r. urzędy gminy zamieszkania właściciela pojazdu, następnie od 1990 do 1998 r. urzędy rejonowe, a od 1999 r. - starostwa powiatowe). Zakres gromadzonych w ewidencji informacji o pojazdach obejmował przede wszystkim podstawowe dane techniczne, tzn.: markę, model, rodzaj pojazdu rok produkcji, pojemność silnika, dopuszczalną ładowność, rodzaj paliwa itp. Natomiast GUS udostępniał informację o liczbie samochodów (wg rodzajów) na poziomie kraju i województw.

Sposób gromadzenia i udostępniania danych o samochodach miał się istotnie zmienić po powstaniu centralnej ewidencji pojazdów. Początkowo zakładano, że nastąpi to w połowie 1999 r. i taką regulację zamieszczono w Ustawie z 1997 r. - Prawo o ruchu drogowym, wprowadzając jednocześnie przepis o zakończeniu funkcjonowania WEP z dniem 30 czerwca 1999 r. Fakt ten wywołał powszechną konsternację związaną z tym, że do tego dnia nie przystąpiono nawet do wyłonienia wykonawcy nowej centralnej bazy (Centralna Ewidencja..., 2003). W ustawie z 1997 r. założono, że od 1 lipca 1999 r. zacznie działać centralna ewidencja pojazdów (a więc dzień wcześniej przestaną funkcjonować WEP), jednak okazało się to zupełnie niemożliwe, dlatego kilka miesięcy później wprowadzono nowelizację przepisów (ustawa przyjęta 31 marca 2000 r.) i przywrócono WEP wraz z koniecznością ich aktualizacji przez starostów i prezydentów miast. Niemniej jednak przez prawie rok starostwa nie miały obowiązku wprowadzania danych rejestrowanych pojazdów do WEP (kilka z nich publicznie informowało, że tego nie robi z uwagi na brak podstawy prawnej - zob. Bienias, 1999; Burzyński i Bienias, 1999). Z tego względu ciągłość gromadzonych informacji została zaburzona, a w efekcie bazy powiatowe i wojewódzkie różniły się co do zawartości.

W 2003 r. Ministerstwo Spraw Wewnętrznych i Administracji (MSWiA) rozpoczęło konsultacje koncepcji budowy, wdrożenia i eksploatacji nowego systemu informatycznego centralnej ewidencji pojazdów. Opublikowane przez MSWiA materiały wyjściowe pokazywały szereg problemów, które utrudniały integrację danych powiatowych i wojewódzkich. Okazało się bowiem, że ewidencje lokalne i regionalne korzystały z sześciu odmiennych języków programowania, siedmiu systemów operacyjnych i pięciu środowisk bazodanowych (a niektóre lokalne jednostki tworzyły systemy oparte na własnych, indywidualnych rozwiązaniach bazodanowych). Do tego dochodziły problemy z możliwościami eksportowania baz lokalnych, używaniem różnych słowników (kodów określających poszczególne cechy pojazdu) i brakiem dostępu do sieci LAN w ok. 1/5 starostw powiatowych (Centralna Ewidencja..., 2003, s. 12). Mimo to MSWiA pod koniec października 2003 r. podpisało umowę z wykonawcą na uruchomienie pierwszej wersji CEP do końca grudnia 2003 r. Bazę uruchomiono 1 stycznia 2004 r., jednak jej oceny publikowane wówczas w prasie branżowej i codziennej były bardzo krytyczne. Można nawet stwierdzić, że pierwsza wersja CEP była w dużym stopniu niefunkcjonalna z uwagi na jakość danych, które zostały pobrane z baz lokalnych i regionalnych. Dodatkowo zbiegło się to z uruchomieniem podsystemu informatycznego „Pojazd”, który odpowiadał za rejestrację aut w starostwach oraz dużą skalą nowych pojazdów na polskim rynku w związku z wstąpieniem Polski do Unii Europejskiej. Okazało się wówczas także, że stosunkowo dużą liczbę informacji o pojazdach (dotyczyło to zbioru ok. $1 \mathrm{mln}$ samochodów) trzeba było wpisać ręcznie, ponieważ nowopowstały system nie potrafił przetworzyć istniejących danych (Samcik, 2005).

Pierwotnie planowana finalizacja budowy CEP w pełnej funkcjonalności miała nastąpić z końcem 2006 r. Datę tę przesuwano kilkukrotnie w związku z koniecznością budowy infrastruktury towarzyszącej (bunkra do przechowywania kopii danych z systemu oraz sie- 
ci łączności pozwalającej na bieżące odczytywanie i aktualizowanie danych). Problemem była także integracja systemu CEP prowadzonego przez MSWiA z systemem "Pojazd”, zarządzanym przez Ministerstwo Transportu (trudności współpracy międzysektorowej). Ostatecznie dopiero w 2009 r. GUS zaczął publikować dane z CEP (w tym na poziomie powiatów), jednak baza ta ciągle nie uzyskała funkcjonalności, której od niej oczekiwano, tzn. nie integrowała informacji z szeregu różnych istotnych zbiorów danych, w tym m.in. z bazy Ubezpieczeniowego Funduszu Gwarancyjnego - UFG (informacje o ubezpieczeniach OC) lub stacji kontroli pojazdów. To z kolei oznaczało, że weryfikacja liczby pojazdów zarejestrowanych w ewidencji nie będzie możliwa (a dane UFG już wtedy pokazywały, że jest ona najpewniej zawyżona aż o kilka milionów).

Stan ten miał się w końcu zmienić po uruchomieniu tzw. CEP 2.0. Ministerstwo Spraw Wewnętrznych i Administracji podpisało w 2013 r. umowę z Centralnym Ośrodkiem Informatyki na realizację drugiej generacji CEP, która miała zakończyć się w 2016 r. Termin ten ponownie nie został dotrzymany i CEP 2.0 uruchomiono dopiero w listopadzie 2017 r. Od tego momentu zaczęto gromadzić w tej bazie znacznie większą ilość informacji o pojazdach i kierowcach, choć ich jakość jest bardzo różna. Obecnie funkcjonowanie centralnej ewidencji pojazdów reguluje zmieniona ustawa Prawo o ruchu drogowym (Dziennik Ustaw, 2020) oraz rozporządzenie Ministra Cyfryzacji z dnia 25 maja 2018 r. w sprawie katalogu danych gromadzonych w centralnej ewidencji pojazdów (Ministerstwo Cyfryzacji, 2018). W świetle tych dwóch dokumentów w ewidencji gromadzone są informacje obejmujące 60 różnych cech opisujących dane techniczne każdego pojazdu. Wśród nich są m.in.: marka, model, rodzaj pojazdu, rok produkcji, rok pierwszej rejestracji w Polsce. Część danych ma jednak niską jakość informacyjną z uwagi na braki lub błędne nazwy (kilka takich przykładów podano w tab. 2). Ułomności danych CEP ograniczają jej wykorzystanie badawcze, jednak trzeba podkreślić, że nawet z tymi trudnościami jest to bardzo szczegółowe i cenne źródło danych, umożliwiające prowadzenie wielu badań motoryzacyjnych o znacznie większej wiarygodności niż wcześniejsze.

\section{Skala ułomności statystyki motoryzacji w Polsce oraz ich rozkład przestrzenny}

\section{„Martwe dusze”, czyli tzw. pojazdy archiwalne}

Powstanie CEP 2.0 i integracja różnych baz danych związanych z pojazdami dała możliwość weryfikacji liczby samochodów osobowych w Polsce, które z dużym prawdopodobieństwem - oprócz faktu rejestracji - realnie poruszają się po polskich drogach. Dzięki temu, od listopada 2017 r., dla każdego pojazdu zarejestrowanego w Polsce określa się tzw. stan pojazdu, czyli cechę, która przyjmuje jedną z dwóch wartości - ZAR-A (pojazd zarejestrowany archiwalny) lub ZAR (pojazd zarejestrowany niearchiwalny). Jak już wcześniej wspomniano (tab. 2), stan ZAR-A oznacza samochód niewyrejestrowany i nieanulowany, inny niż zabytkowy, dla którego upłynęło ponad 10 lat od daty pierwszej rejestracji w Polsce i w okresie od 6 lat od daty bieżącej nie wpłynął żaden komunikat aktualizujący z organu rejestracyjnego, UFG, stacji kontroli pojazdów lub policji. Pojazdy niespełniające tych kryteriów określa się mianem zarejestrowanych niearchiwalnych (ZAR). Stan archiwalny jest możliwy do zmiany przez starostę, stację kontroli pojazdów, UFG i policję w trakcie procesów związanych ze standardowymi czynnościami wykonywanymi przez te podmioty w związku z ewidencją pojazdów. 
Tabela 2. Przykładowe cechy pojazdu i właściciela udostępniane z CEP oraz problemy obniżające ich jakość informacyjną

Selected vehicle and ownership characteristics and their information weaknesses

\begin{tabular}{|c|c|c|c|}
\hline Nazwa cechy & $\begin{array}{l}\text { Odsetek sam. } \\
\text { os. z brakiem } \\
\text { informacji } \\
\text { o cesze }\end{array}$ & $\begin{array}{l}\text { Liczba } \\
\text { unika- } \\
\text { towych } \\
\text { wartości }\end{array}$ & Problemy \\
\hline marka & 0,001 & 5769 & $\begin{array}{l}\text { duża liczba błędów technicznych („literówki” w na- } \\
\text { zwach) oraz brak jednolitych słowników marek }\end{array}$ \\
\hline model & 0,213 & 341830 & $\begin{array}{l}\text { duża liczba błędów technicznych („literówki” w na- } \\
\text { zwach) oraz brak jednolitych słowników modeli }\end{array}$ \\
\hline rok produkcji & - & 151 & $\begin{array}{l}\text { pojawiają się ewidentne błędy (choć jest ich relatywnie } \\
\text { niewiele), np. rok produkcji: 1000, 1069, } 1111\end{array}$ \\
\hline rodzaj paliwa & 0,475 & 17 & $\begin{array}{l}\text { ponad } 98 \% \text { samochodów przypisano benzynę (w } 3 \text { wa- } \\
\text { riantach) lub olej napędowy }\end{array}$ \\
\hline średnie zużycie paliwa & 85,619 & 583 & $\begin{array}{l}\text { bardzo duża liczba braków informacji wynika z tego, } \\
\text { że jest to nowa cecha, wprowadzona dopiero w CEP } \\
\text { 2.0. Wśród samochodów wyprodukowanych w } 2017 \text { lub } \\
2018 \text { r. odsetek braków wynosi już tylko ok. } 11 \%\end{array}$ \\
\hline $\begin{array}{l}\text { indywidualne pozio- } \\
\text { my emisji } \mathrm{CO}^{2}\end{array}$ & 83,134 & 763 & $\begin{array}{l}\text { bardzo duża liczba braków informacji wynika z tego, } \\
\text { że jest to nowa cecha, wprowadzona dopiero w CEP } \\
\text { 2.0. Wśród samochodów wyprodukowanych w } 2017 \text { lub } \\
2018 \text { r. odsetek braków wynosi już tylko ok. } 10 \%\end{array}$ \\
\hline stan pojazdu & - & 2 & $\begin{array}{l}\text { cecha przyjmuje jedną z dwóch wartości: stan } \\
\text { ZAR-A (zarejestrowany archiwalny) uzyskują pojazdy } \\
\text { niewyrejestrowane i nieanulowane, inne niż zabytkowe, } \\
\text { dla których upłynęło ponad } 10 \text { lat od daty pierwszej re- } \\
\text { jestracji i w okresie od } 6 \text { lat od daty bieżącej nie wpłynął } \\
\text { żaden komunikat aktualizujący z organu rejestracyjnego, } \\
\text { UFG, stacji kontroli pojazdów lub Policji. Stan ZAR (po- } \\
\text { jazd zarejestrowany niearchiwalny) otrzymują pojazdy, } \\
\text { które nie spełniają tych warunków }\end{array}$ \\
\hline $\begin{array}{l}\text { powiat zamieszkania/ } \\
\text { prowadzenia działal- } \\
\text { ności przez właściciela }\end{array}$ & - & 399 & $\begin{array}{l}\text { oprócz poprawnych kodów TERYT powiatów występują } \\
\text { także nieliczne, które nigdy nie istniały oraz kody dla } \\
\text { gmin warszawskich }\end{array}$ \\
\hline $\begin{array}{l}\text { gmina zamieszkania/ } \\
\text { prowadzenia działal- } \\
\text { ności przez właściciela }\end{array}$ & 5,770 & 3829 & $\begin{array}{l}\text { stosunkowo duża liczba braków kodów TERYT - błąd } \\
\text { możliwy do minimalizacji przez uwzględnienie kodów } \\
\text { powiatu; duża liczba wartości unikatowych wynika } \\
\text { przede wszystkim ze zmiany kodu TERYT gminy (m.in. } \\
\text { wskutek uzyskania statusu miasta lub zmiany przynależ- } \\
\text { ności powiatowej) }\end{array}$ \\
\hline
\end{tabular}

Według danych z 31 grudnia 2018 r. ponad 6 mln samochodów osobowych (czyli ok. $26 \%$ wszystkich zarejestrowanych) posiadało status pojazdu archiwalnego. Jest to stosunkowo duża wartość, która w znacznym stopniu zawyża wskaźnik motoryzacji w Polsce. Okazuje się, że po odliczeniu pojazdów archiwalnych powinien on kształtować się na poziomie ok. 450 samochodów na 1000 mieszkańców, co sytuowałoby Polskę w okolicach 20. miejsca wśród 28 państw Unii Europejskiej. To dość istotna zmiana, biorąc pod uwagę wielość i rangę decyzji, które są podejmowane w oparciu o wartość tego wskaźnika (osobną sprawą jest pytanie, czy w innych państwach postsocjalistycznych nie zachodzi na podobną skalę to samo zjawisko). 
Analiza wieku samochodów archiwalnych (ryc. 2) potwierdza, że są to głównie samochody bardzo stare (por. Komornicki, 2011). Blisko 64\% pojazdów archiwalnych stanowią samochody wyprodukowane przed 1990 r. (czyli starsze niż 30 lat). Z kolei auta wyprodukowane po 2000 r. stanowią tylko ok. 1\% wszystkich pojazdów archiwalnych. Analiza marek i modeli dowodzi, że wśród pojazdów archiwalnych przeważają głównie: Fiat 126 P, Fiat 125 P i Polonez. Są to więc auta w znacznej części wyprodukowane w Polsce i tu po raz pierwszy zarejestrowane (72\% samochodów archiwalnych to auta zarejestrowane w Polsce po raz pierwszy w roku ich produkcji lub rok później). Jest zatem bardzo duże prawdopodobieństwo, że większość z ponad $6 \mathrm{mln}$ aut archiwalnych nie porusza się po polskich drogach już przynajmniej od 20 lat. Wśród „martwych dusz” istnieje także dość liczna grupa samochodów importowanych, rejestrowanych w Polsce głównie w momentach ważnych zmian instytucjonalnych, czyli w latach 1990-1991 (początek transformacji) oraz 2004-2006 (pierwsze lata członkostwa w Unii Europejskiej) (ryc. 2). Dane pokazują, że spośród aut osobowych zarejestrowanych w Polsce po raz pierwszy w 1991 r., blisko 0,5 mln do dziś widnieje w ewidencji, choć są uznane za pojazdy archiwalne.

Rozkład przestrzenny udziału pojazdów archiwalnych w ogólnej liczbie samochodów osobowych (ryc. 3) pokazuje, że istnieją obszary szczególnej koncentracji tego zjawiska. Wydaje się jednak, że nie mają one większego związku z lokalizacją Państwowych Gospodarstw Rolnych - PGR (co zakładał T. Komornicki, 2006, 2011). Na terenach dawnych województw: szczecińskiego, koszalińskiego, słupskiego i gorzowskiego (obszary najwięk-
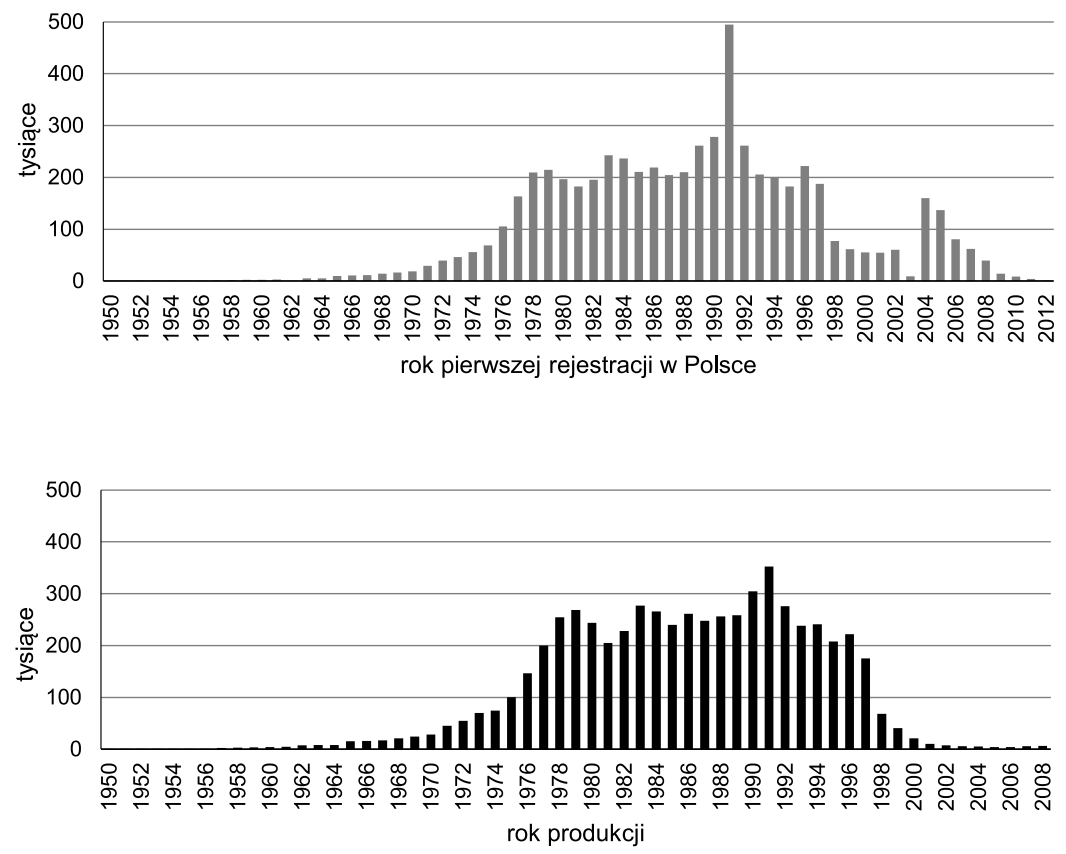

Ryc. 2. Pojazdy archiwalne wg roku produkcji i roku pierwszej rejestracji w Polsce (stan na 31.12.2018) End-of-life vehicles by their years of production and first registration in Poland Opracowanie własne na podstawie danych z Centralnej Ewidencji Pojazdów.

Authors' own elaboration based on data from the Central Vehicle Register (Centralna Ewidencja Pojazdów). 


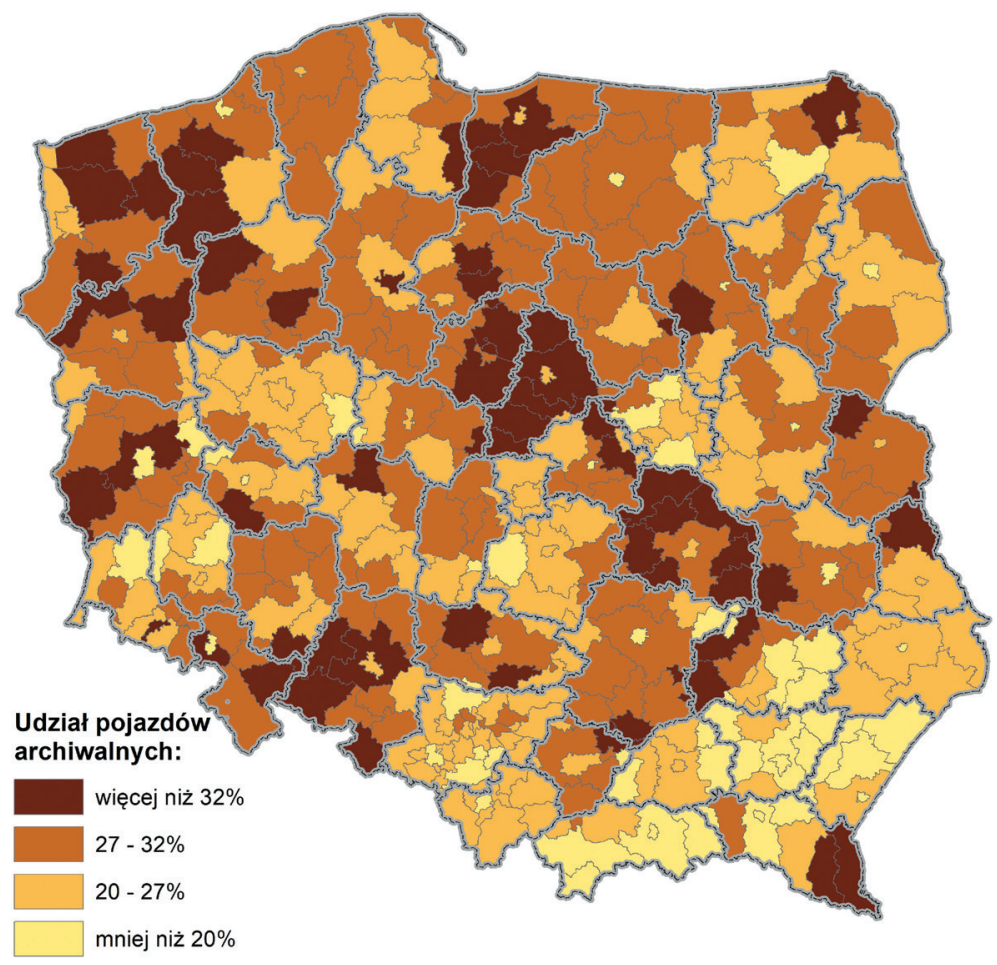

Ryc. 3. Rozkład przestrzenny pojazdów archiwalnych w powiatach w Polsce (stan na 31.12.2018) na tle podziału administracyjnego na 49 województw (1975-1998)

Spatial distribution of end-of-life cars in Poland (as of 31.12.2018), in line with country's former division into 49 voivodeships (1975-1998)

Opracowanie własne na podstawie danych z Centralnej Ewidencji Pojazdów Authors' own elaboration based on data from Central Vehicle Register (Centralna Ewidencja Pojazdów).

szej koncentracji gruntów PGR) udział pojazdów archiwalnych jest zbliżony do średniej krajowej (ok. 26\%). Na mapie bardziej zaznaczają się prawidłowości przestrzenne związane z historycznym układem administracyjnym 49 województw - największą koncentrację pojazdów archiwalnych można bowiem zaobserwować w dawnych województwach: płockim (34\%), radomskim (31\%), elbląskim (30\%) i wałbrzyskim (30\%). Ma to najprawdopodobniej związek z tym, że niektóre urzędy wojewódzkie dokonały w latach 90. XX w. korekty w prowadzonych ewidencjach, inne z kolei tego nie zrobiły, co wskazywał w swojej pracy T. Komornicki (2011).

\section{„Auta z kratką", czyli samochody osobowe z homologacją ciężarową}

Drugim elementem, wpływającym na jakość statystyki motoryzacji w Polsce, jest niedoszacowanie liczby samochodów osobowych w związku z występowaniem zjawiska „aut z kratką", czyli samochodów osobowych z homologacją ciężarową. Formalnie są to samochody ciężarowe (i tak są ewidencjonowane), w praktyce jednak pełnią funkcję samochodów osobowych lub osobowo-ciężarowych. Nie są one (choć powinny być) włączane 
do statystyk pokazujących poziom motoryzacji w Polsce, zaniżając tym samym jego wielkość. To niedoszacowanie jest różne w poszczególnych częściach Polski.

Według danych CEP, 31 grudnia 2018 r. zarejestrowanych było w Polsce ponad 3,3 m/n samochodów ciężarowych, z czego niewiele ponad $1 \mathrm{mln}(30 \%)$ to tzw. „martwe dusze”. Oznacza to, że park samochodów ciężarowych w Polsce tworzy realnie ok. 2,3 mln pojazdów, a część z nich to de facto samochody osobowe z homologacją ciężarową. Określenia wielkości niedoszacowania liczby samochodów osobowych w związku z problemem „aut z kratką" dokonywano dotychczas poprzez odwołanie się do wartości opisujących pojazdy na skali tzw. dopuszczalnej ładowności. W dużym skrócie, określa ona różnicę pomiędzy dopuszczalną masą całkowitą a masą własną pojazdu i jest jedną z informacji o samochodzie gromadzoną w zbiorach CEP. Granicą, jaką przyjmowano dotąd najczęściej w celu oddzielenia od grupy samochodów ciężarowych tych, które są także (lub przede wszystkim) wykorzystywane jako osobowe, była dopuszczalna ładowność mniejsza niż 1,5 tony. Według stanu na 31 grudnia 2018 r. w Polsce zarejestrowanych było ok. 1,88 mln tego typu pojazdów. Trzeba jednak dodać, że zbiór ten jest dość szeroki i można w nim wyróżnić kilka podgrup, w których prawdopodobieństwo osobowego wykorzystywania samochodu jest zróżnicowane. W związku z tym konieczna jest bardziej pogłębiona analiza uwzględniająca nie tylko kryterium dopuszczalnej ładowności, ale także liczby miejsc przeznaczonych dla pasażerów pojazdu.

Z punktu widzenia typu pojazdu, samochody ciężarowe o dopuszczalnej ładowności nieprzekraczającej 1,5 tony możemy podzielić korzystając z popularnych segmentacji pojazdów (np. Baltas i Saridakis, 2013; Lansley, 2016) na trzy główne grupy:

(1)średnie dostawcze (np. Volkswagen Transporter, Fiat Ducato, Ford Transit, Mercedes Sprinter, Renault Master, Peugeot Boxer);

(2)kombivany (np. Citroen Berlingo, Peugeot Partner, Renault Kangoo, Volkswagen Caddy, Fiat Doblo i Opel Combo);

(3)pozostałe auta reprezentujące różne segmenty podstawowe samochodów osobowych $^{1}$ (wśród nich najpopularniejsze są Fiat Panda, Skoda Octavia, Fiat Seicento, Skoda Fabia, Opel Astra, Renault Megane i Ford Focus).

Wśród wszystkich 1,88 mln samochodów ciężarowych o dopuszczalnej ładowności poniżej 1,5 tony zdecydowaną większość stanowią pojazdy z grupy pierwszej (ok. 64\%) i drugiej (ok. 18\%), które trudno jest automatycznie włączyć do grupy pojazdów osobowych. Część z nich wykorzystywana jest w zasadzie wyłącznie do przewozu ładunków. Jako dodatkowe kryterium rozróżnienia pojazdów osobowych od ciężarowych można zastosować w tym przypadku liczbę miejsc przeznaczonych dla pasażerów. W odniesieniu do samochodów z segmentu średnie dostawcze dolną granicę ich osobowego użytkowania można określić na poziomie trzech pasażerów (na ogół modele samochodów z tego segmentu mają trzy miejsca do siedzenia w pierwszym rzędzie, w tym jedno kierowcy), z kolei w segmencie kombivany - na poziomie dwóch. Włączając zatem do grupy samochodów osobowych całą trzecią ww. grupę, a także auta średnie dostawcze z przynajmniej czterema miejscami oraz kombivany z przynajmniej trzema miejscami do siedzenia (wraz

${ }^{1}$ Określenie „segmenty podstawowe samochodów osobowych” utożsamiamy z segmentacją pojazdów stosowaną przez Komisję Europejską obejmującą segmenty od A (tzw. samochody mini, np. Fiat 500) do F (stosunkowo duże auta luksusowe) (Thiel i inni, 2014). Jest to klasyfikacja obejmująca pojazdy wykorzystywane wyłącznie w celach przewozu osób, zarówno kombivany, jak i pojazdy dostawcze. 
z miejscem kierowcy), otrzymujemy liczbę ok. 750 tys. pojazdów, która może stanowić maksymalną granicę liczby aut osobowych z homologacją ciężarową.

Rozkład przestrzenny występowania aut ciężarowych o dopuszczalnej ładowności do 1,5 tony w podziale na wyróżnione grupy zamieszczono na rycinie 4 . Większa reprezentacja aut z segmentów podstawowych oraz kombivanów jest widoczna głównie w dużych miastach oraz strefach podmiejskich (jest to szczególnie widoczne w przypadku aut z segmentów podstawowych). Ma to z pewnością związek z lokalizacją firm leasingowych oraz rynkiem tzw. samochodów poleasingowych, które są na ogół kupowane przez mieszkańców dużych miast lub stref podmiejskich. Z kolei w przypadku aut w segmencie średnie dostawcze widoczna jest ich ponadprzeciętnie duża reprezentacja w tzw. powiatach sadowniczych (grójecki, białobrzeski, rawski, sandomierski, opolski).

Wnioski te potwierdza prosta analiza korelacji pomiędzy liczbą samochodów ciężarowych na 1000 mieszkańców w poszczególnych segmentach a czterema wybranymi wskaźnikami (tab. 3). Zmienna opisująca udział sadów w ogólnej powierzchni potwierdza
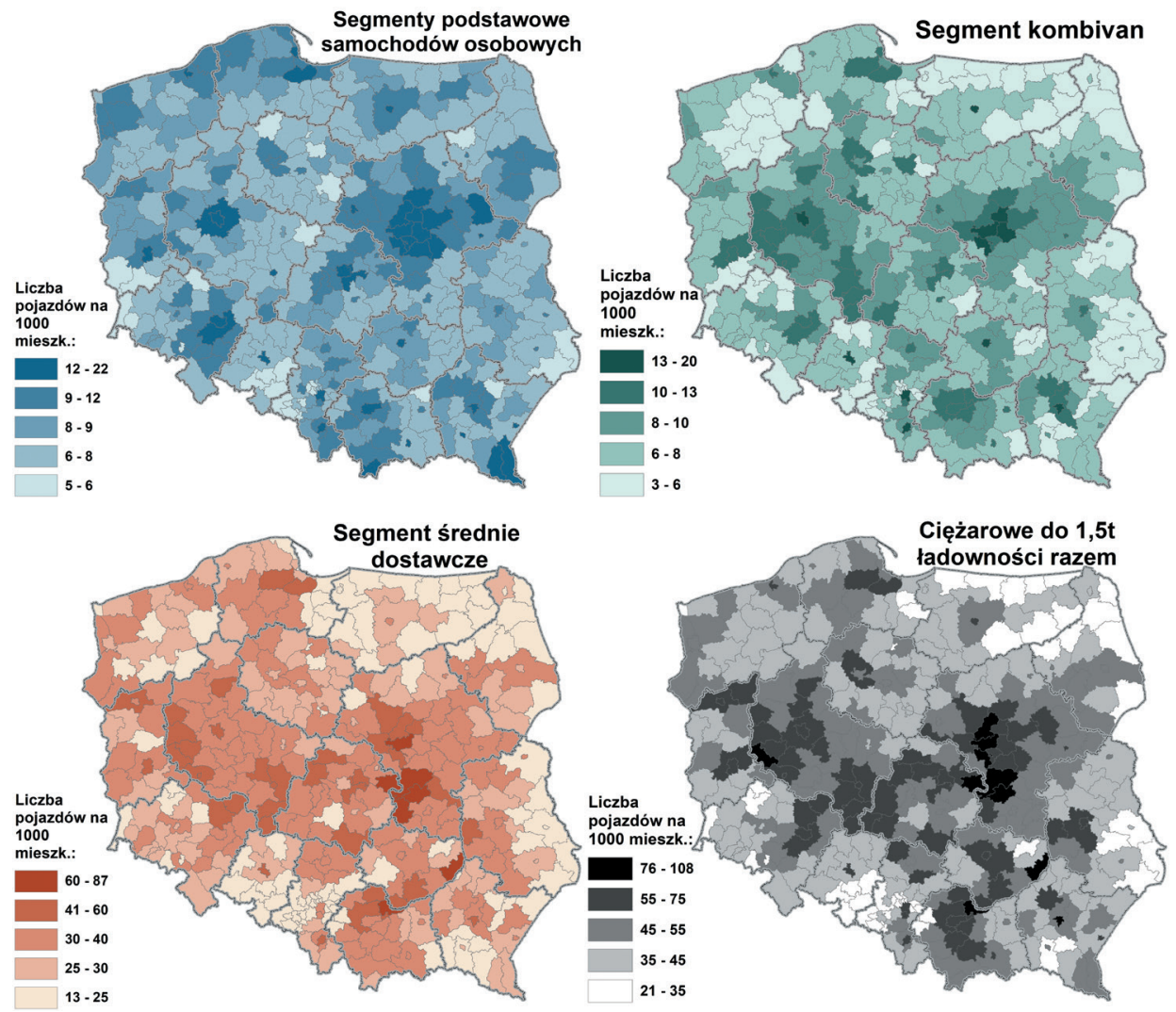

Ryc. 4. Rozkłady przestrzenne wartości wskaźnika liczby samochodów ciężarowych (dopuszczalna ładowność $<1,5$ t) na 1000 mieszkańców w Polsce w układzie trzech wybranych grup (stan na 31.12.2018)

Spatial distribution of heavy goods vehicles (permissible load capacity < 1.5 t) per 1000 inhabitants in Poland in three segments

Opracowanie własne na podstawie danych z Centralnej Ewidencji Pojazdów.

Authors' own elaboration based on data from Central Vehicle Register (Centralna Ewidencja Pojazdów). 
Tabela 3. Współczynniki korelacji pomiędzy liczbą samochodów ciężarowych (dopuszczalna ładowność < 1,5 t) na 1000 mieszkańców wg segmentów a wybranymi cechami społeczno-ekonomicznymi Correlation coefficients between the number of heavy goods vehicles (permissible load capacity < $1.5 \mathrm{t}$ ) per 1000 inhabitants by their segments and selected socio-economic features

\begin{tabular}{|l|c|c|c|c|}
\hline \multicolumn{1}{|c|}{ Segment } & $\begin{array}{c}\text { gęstość } \\
\text { zaludnienia }\end{array}$ & $\begin{array}{c}\text { wpływy z podatku od środków } \\
\text { transportowych na 1 mieszk. }\end{array}$ & $\begin{array}{c}\text { wpływy z PIT } \\
\text { na 1 mieszk. }\end{array}$ & $\begin{array}{c}\text { udział sadów } \\
\text { w ogólnej pow. }\end{array}$ \\
\hline segmenty podstawowe & $0,312^{* *}$ & $0,328 * *$ & $0,603 * *$ & 0,088 \\
kombi van & $0,271^{* *}$ & $0,456 * *$ & $0,564 * *$ & 0,075 \\
średnie dostawcze & $-0,128^{*}$ & $0,383^{* *}$ & 0,063 & $0,502 * *$ \\
\hline
\end{tabular}

** korelacja istotna statystycznie na poziomie $\alpha<0,01$

* korelacja istotna statystycznie na poziomie $\alpha<0,05$

Opracowanie własne na podstawie danych z Centralnej Ewidencji Pojazdów

Authors' own elaboration based on data from Central Vehicle Register (Centralna Ewidencja Pojazdów).

relatywnie silny i istotny statystycznie związek z liczbą samochodów z segmentu średnie dostawcze. Z kolei wpływy z PIT na 1 mieszkańca (najwyższe w dużych miastach i ich strefach podmiejskich) wykazują relatywnie silny związek z liczbą samochodów w segmentach osobowe i kombivan.

\section{Samochody firmowe}

„Martwe dusze” i „auta z kratką” to pojazdy, które wpływają istotnie na ogólną liczbę samochodów osobowych w Polsce, wykorzystywaną do określania poziomu motoryzacji w badaniach międzynarodowych. Trzecia analizowana ułomność (związana z autami firmowymi) nie zmienia tej ogólnej wartości miernika, wpływa jednak na jego rozkład przestrzenny, zwiększając liczbę samochodów w stosunkowo niewielkiej grupie gmin i powiatów. Auta firmowe są często przedmiotem odrębnych analiz i stanowią w pewnym sensie „autonomiczną" zmienną kształtującą poziom motoryzacji (de Jong i inni, 2007; Whelan, 2007).

Samochody firmowe są powszechną praktyką, stosowaną głównie w średnich i dużych przedsiębiorstwach, jako swego rodzaju „dodatek do wynagrodzenia” dla personelu średniego i wysokiego szczebla lub przedstawicieli handlowych. To sytuacja znana nie tylko z Polski, ale także z wielu innych krajów, m.in. Wielkiej Brytanii (Whelan, 2007). W danych ewidencyjnych samochody firmowe wykazywane są zgodnie z lokalizacją siedziby właściciela pojazdu, czyli firmy leasingowej.

Według stanu na koniec 2018 r. w Polsce zarejestrowanych było blisko 1,5 mln firmowych samochodów osobowych (ok. 10\% wszystkich zarejestrowanych samochodów osobowych z wyłączeniem pojazdów archiwalnych). Wielkość floty aut firmowych w 15 gminach z ich największą liczbą zamieszczono w tabeli 4. Widać wyraźnie, że ok. 30\% wszystkich aut firmowych jest zarejestrowanych w Warszawie, a kolejne 30\% w pięciu dużych polskich miastach: Poznaniu, Wrocławiu, Krakowie, Gdańsku i Łodzi. Wśród 15 gmin z największą liczbą aut firmowych jest tylko jedna mała gmina - Kampinos. Wysoki poziom motoryzacji w tej jednostce jest wynikiem polityki podatkowej miejscowego samorządu, który przyciągnął firmy leasingowe po to, by uzyskiwać większe wpływy z podatku od środków transportowych, który jest podatkiem lokalnym (co prawda samochody osobowe nie są nim objęte, ale bardzo często firmy leasingowe mają w swojej ofercie jednocześnie zarówno pojazdy osobowe jak i ciężarowe). Podobne zjawisko obserwujemy w gminach: 
Tabela 4. Piętnaście miast i gmin w Polsce z największą liczbą samochodów firmowych The fifteen municipalities in Poland with the largest numbers of fleet cars

\begin{tabular}{|c|c|c|c|c|c|c|}
\hline \multirow{2}{*}{ Lp } & \multirow{2}{*}{ Miasto/gmina } & \multicolumn{2}{|c|}{$\begin{array}{l}\text { Liczba samochodów osobowych } \\
\text { zarejestrowanych przez }\end{array}$} & \multicolumn{3}{|c|}{$\begin{array}{l}\text { Liczba samochodów osobowych } \\
\text { na } 1000 \text { mieszkańców }\end{array}$} \\
\hline & & osoby fizyczne & $\begin{array}{l}\text { podmioty } \\
\text { gospodarcze }\end{array}$ & osoby fizyczne & $\begin{array}{l}\text { podmioty } \\
\text { gospodarcze }\end{array}$ & razem \\
\hline 1 & Warszawa & 591643 & 424988 & 337 & 242 & 578 \\
\hline 2 & Poznań & 192088 & 96411 & 356 & 179 & 535 \\
\hline 3 & Wrocław & 223571 & 89406 & 350 & 140 & 490 \\
\hline 4 & Kraków & 269860 & 88201 & 352 & 115 & 467 \\
\hline 5 & Katowice & 101949 & 59623 & 343 & 201 & 544 \\
\hline 6 & Gdańsk & 148380 & 46056 & 320 & 99 & 419 \\
\hline 7 & Łódź & 241237 & 43812 & 348 & 63 & 411 \\
\hline 8 & Szczecin & 134205 & 27073 & 332 & 67 & 399 \\
\hline 9 & Rzeszów & 67972 & 24474 & 359 & 129 & 489 \\
\hline 10 & Lublin & 122279 & 24424 & 359 & 72 & 431 \\
\hline 11 & Gdynia & 83067 & 24194 & 337 & 98 & 435 \\
\hline 12 & Kampinos & 2261 & 21456 & 527 & 4998 & 5525 \\
\hline 13 & Bydgoszcz & 114726 & 21438 & 325 & 61 & 385 \\
\hline 14 & Bielsko-Biała & 67901 & 20150 & 395 & 117 & 512 \\
\hline 15 & Opole & 48270 & 16671 & 377 & 130 & 507 \\
\hline
\end{tabular}

Opracowanie własne na podstawie danych z Centralnej Ewidencji Pojazdów. Authors' own elaboration based on data from Central Vehicle Register (Centralna Ewidencja Pojazdów).

Cedry Wielkie, Nadarzyn i Suchy Las. Drugim czynnikiem decydującym o dużej liczbie samochodów firmowych jest wysoki poziom aktywności gospodarczej gminy i obecność wielu dużych przedsiębiorstw (przykładem mogą być znowu duże miasta lub silnie zainwestowane gminy podmiejskie, takie jak Tarnowo Podgórne lub Kobierzyce).

W związku z wyraźnie nierównomiernym rozkładem przestrzennym samochodów firmowych powinno wyłączać się je z analiz poziomu motoryzacji w gminach lub powiatach. Wiadomo bowiem, że znaczna część tych pojazdów użytkowana jest w zupełnie innym miejscu niż miasto/gmina rejestracji.

\section{Podsumowanie - konsekwencje identyfikacji ułomności statystyki motoryzacji dla badań geograficznych i praktyki planistycznej}

W obliczu szybkiego przyrostu danych statystycznych, coraz łatwiejszego ich pozyskiwania i przetwarzania zaobserwować można relatywnie niskie zainteresowanie ich jakością. Dotyczy to również badań geograficznych, w których stosowanie zawyżonych lub zaniżonych wartości wskaźników statystycznych może prowadzić do zdeformowanego obrazu przestrzennego występowania i dynamiki danego zjawiska lub procesu, a w konsekwencji do błędnych interpretacji i niewłaściwych działań praktycznych. 
Zniekształcenia wskaźników motoryzacyjnych mają w badaniach geograficznych konsekwencje dwojakiego rodzaju: bezpośrednie i pośrednie. Konsekwencje bezpośrednie polegają na tym, że skorygowanie wartości wskaźnika często diametralnie zmienia rozkład przestrzenny poziomu (lub dynamiki) motoryzacji oraz pozycję danej jednostki terytorialnej (kraju, regionu) na tle innych jednostek. Dobrą ilustracją tego rodzaju rozbieżności jest porównanie map poziomu motoryzacji w Polsce wykonanych na podstawie danych GUS oraz CEP, skorygowanych przez zespół autorski tego artykułu (ryc. 5). Korekta ta polega na odjęciu od ogólnej liczby zarejestrowanych samochodów, samochodów archiwalnych oraz firmowych i dodaniu aut osobowych z homologacją ciężarową (wg kryteriów określonych w rozdziale "Auta z kratkq”, czyli samochody osobowe z homologacjq ciężarowq). W przypadku obu wariantów wskaźnika motoryzacji operujemy układem decylowym, tzn. zbiór powiatów został podzielony na 10 równolicznych grup uporządkowanych według wskaźnika liczby samochodów na 1000 mieszkańców.

Skalę i rozkład przestrzenny rozbieżności w ocenie poziomu motoryzacji przedstawiono na rycinie 6. Pokazuje ona przesunięcia poszczególnych powiatów w układzie decylowym po dokonaniu autorskiej korekty wskaźnika motoryzacji, a więc zmiany pozycji danego powiatu w zbiorze wszystkich tego typu jednostek w Polsce. W znacznej części powiatów (253, czyli ok. 66\%) te zmiany nie zaszły lub są bardzo niewielkie i zawierają się w przedziale $<-1 ;+1>$. Największe przesunięcia in minus obserwujemy wśród dużych miast (Sopot, Warszawa, Katowice, Wrocław, Poznań), które "tracą” przede wszystkim wskutek odjęcia liczby pojazdów firmowych oraz w grupie powiatów z dużym odsetkiem „martwych dusz” i stosunkowo niewielką liczbą „aut z kratką” (np. powiaty głubczycki, przysuski, sztumski, świdnicki). Z kolei wzrost pozycji na skali wskaźnika motoryzacji obserwujemy wśród powiatów z odwrotnymi cechami, tzn. niewielkim udziałem pojazdów archiwalnych i aut osobowych z homologacją ciężarową.

Konsekwencje pośrednie wiążą się z faktem, że wyniki geograficznych badań poziomu i dynamiki motoryzacji często są wykorzystywane w innych szerszych opracowaniach, dotyczących na przykład czynników rozwoju regionalnego i lokalnego, delimitacji obszarów peryferyjnych, dostępności przestrzennej itp., a także w działalności planistyczno-decyzyjnej (np. projekty budowy nowej infrastruktury transportowej na obszarach o największym lub najmniejszym natężeniu motoryzacji). Przyjęcie niewłaściwych wskaźników poziomu motoryzacji może prowadzić do nietrafionych inwestycji komunikacyjnych. Istnieją bowiem opracowania rządowe (np. Strategia rozwoju..., 2013, s. 36 i 53), w których odwoływano się do błędnych statystyk poziomu motoryzacji indywidualnej w Polsce (ale także do zawyżonej liczby samochodów ciężarowych i autobusów), a na tej podstawie stawiano nietrafne diagnozy. Ma to swoje dalej idące konsekwencje. W ostatnich latach pojawiały się w mediach opiniotwórczych zupełnie oderwane od rzeczywistości teksty, np. „Najbardziej zmotoryzowane państwa w UE. Jesteśmy wysoko w rankingu, ale jeździmy złomem" (Forsal, 2017), „Polacy jednym z najbardziej zmotoryzowanych narodów w Unii Europejskiej” (Bankier, 2018), „W Warszawie niemal trzy razy więcej aut na 1000 mieszkańców niż w Nowym Jorku. Auta pożerają polskie miasta" (Pacholski, 2018), które z kolei kształtowały i kształtują świadomość społeczną i percepcję problemów transportowych kraju, regionów lub miast.

Konieczność dążenia do eliminacji ułomności statystyki motoryzacji (zwłaszcza gdy te ułomności są stosunkowo duże, jak w Polsce) wynika również z potrzeb coraz szybciej rozwijającej się geografii rynku, w tym rynku motoryzacyjnego, zarówno w jej wymiarze 

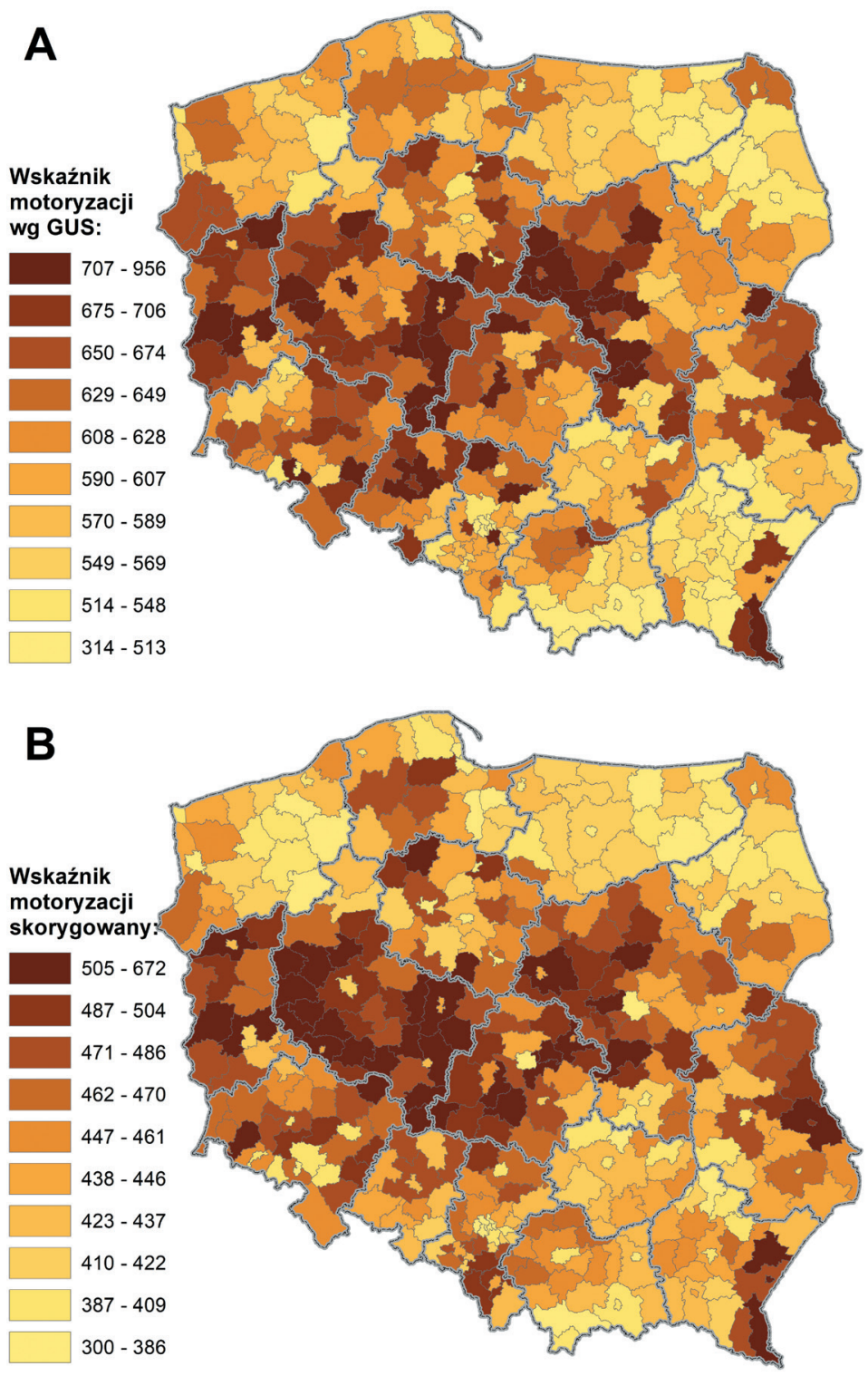

Ryc. 5. Rozkład przestrzenny wartości wskaźnika motoryzacji w Polsce wg danych GUS (A) i CEP po autorskiej korekcie (B) (stan na 31.12.2018)

Spatial distribution of motorisation rate values in Poland, in line with data from Statistics Poland (A) and the Central Vehicle Register (CEP), as corrected by the authors (B) (31.12.2018)

Opracowanie własne na podstawie danych GUS oraz CEP.

Authors' own elaboration based on data from GUS and the CEP.

poznawczym, jak i praktycznym. Przykładowo: dealerzy samochodowi powinni mieć wiarygodną informację w jakich regionach rynek samochodów osobowych jest nasycony, a gdzie występują szczególnie duże „względne niedobory” podaży samochodów. Ta wie- 


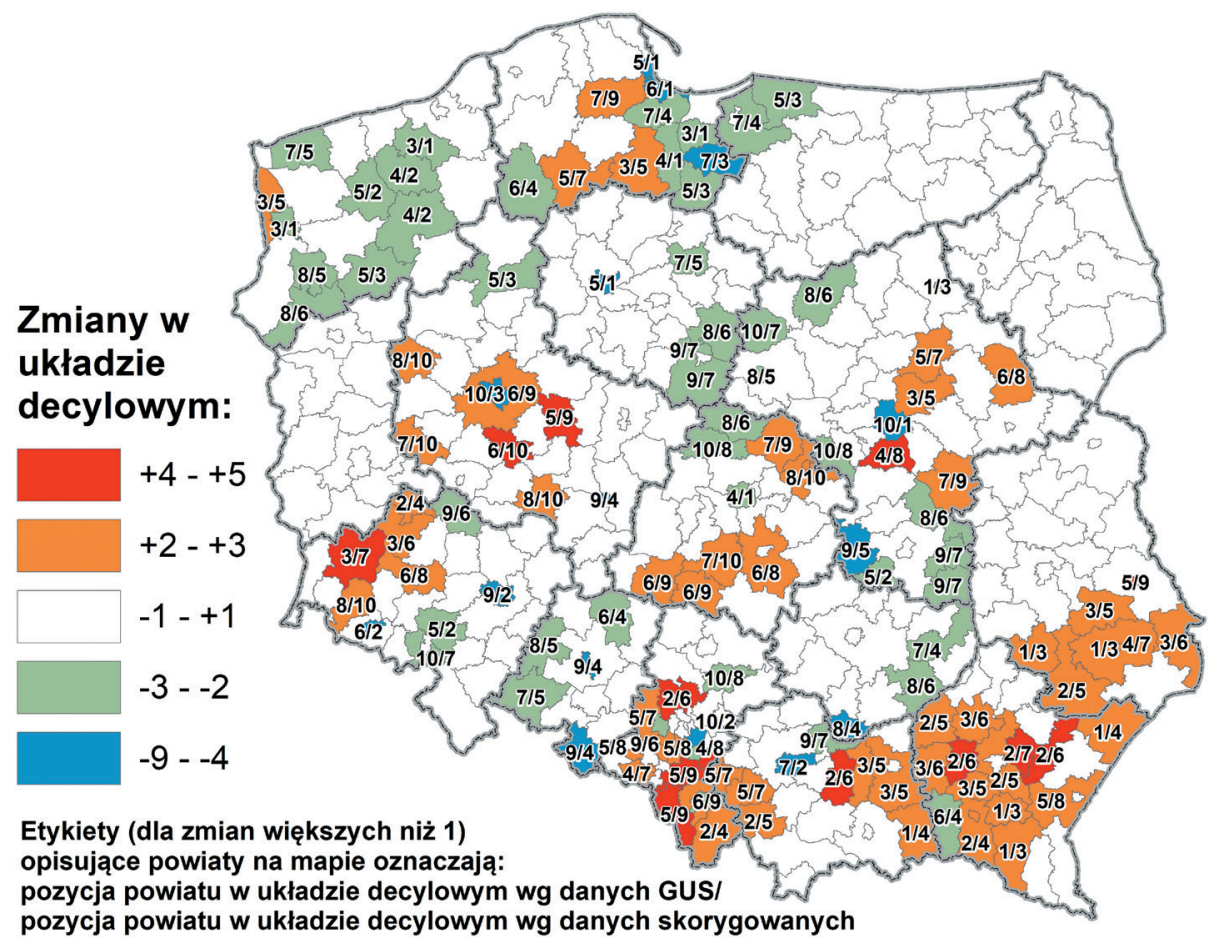

Ryc. 6. Porównanie rozkładu przestrzennego wartości wskaźnika motoryzacji w Polsce wg danych GUS i CEP po autorskiej korekcie (31.12.2018)

Comparison of the spatial distribution of motorisation rate values in Poland, in line with data from GUS and the CEP and following correction by the authors (31.12.2018)

Opracowanie własne na podstawie danych GUS oraz CEP.

Authors' own elaboration based on data from GUS and the CEP.

dza z kolei pociąga za sobą dalsze decyzje lokalizacyjne, dotyczące np. lokalizacji punktów sprzedaży samochodów i innych usług związanych z ich obsługą. Badania geografów, uwiarygodniające zasób danych na temat motoryzacji w wymiarze przestrzennym, ich prawidłowa interpretacja i rekomendacje w sferze planistyczno-decyzyjnej, mogą w istotny sposób przyczynić się do zwiększenia prestiżu naszej dyscypliny i wzrostu jej społecznego znaczenia.

Artykuł powstał w ramach realizacji grantu badawczego „Wymiar przestrzenny (r)ewolucji na rynku samochodowym w Polsce", finansowanego ze środków Narodowego Centrum Nauki (nr projektu 2016/23/B/HS4/00710).

Ryciny i tabele, pod którymi nie zamieszczono źródła, są opracowaniami własnymi autorów artykułu. 


\section{Piśmiennictwo}

Baltas G., Saridakis C., 2013, An empirical investigation of the impact of behavioural and psychographic consumer characteristics on car preferences: An integrated model of car type choice, Transportation Research Part A: Policy and Practice, 54, s. 92-110.

Bankier, 2018, Polacy jednym z najbardziej zmotoryzowanych narodów w Unii Europejskiej, https:// www.bankier.pl/wiadomosc/Polacy-jednym-z-najbardziej-zmotoryzowanych-narodow-w-UniiEuropejskiej-7601441.html (30.08.2019).

Bienias T., 1999, Zapomniana baza, Gazeta Wyborcza, wydanie z 3.09.1999, Dział Kraj, s. 8.

Burzyński L., Bienias T., 1999, Baza nieczynna z powodu, że nie działa, Gazeta Wyborcza, wydanie z 7.07.1999, Tematy Dnia, s. 2.

Centralna Ewidencja Pojazdów i Kierowców, Wykonanie i wdrożenie oraz obsługa eksploatacyjna i rozwój systemu informatycznego, 2003, Ministerstwo Spraw Wewnętrznych i Administracji, Departament Rejestrów Państwowych.

Dargay J., Gately D., Sommer M., 2007, Vehicle ownership and income growth, worldwide: 1960-2030, The Energy Journal, 28, 4, s. 143-170.

Dziennik Ustaw, 2020, Ustawa z dnia 20 czerwca 1997 r. Prawo o ruchu drogowym (Dz. U. z 2020 r. poz. $110,284,568,695)$.

de Jong G.D., Fox J., Daly A., Pieters M., Smit R., 2004, Comparison of car ownership models, Transport Reviews, 24, 4, s. 379-408.

European Commission, 2018, EU Transport in figures - statistical pocketbook 2018, Publications Office of the European Union, Luxembourg, https://publications.europa.eu/en/publication-detail/-/publication/52f721ed-c6b8-11e8-9424-01aa75ed71a1 (30.08.2019).

Forsal, 2017, Najbardziej zmotoryzowane państwa w UE. Jesteśmy wysoko w rankingu, ale jeździmy złomem, https://forsal.pl/artykuly/1053926,najbardziej-zmotoryzowane-panstwa-w-ue-wskazn ik-motoryzacji-polska-europa.html (30.08.2019).

Komornicki T., 2006, Regionalne zróżnicowanie poziomu motoryzacji w świetle danych GUS - ocena krytyczna, [w:] T. Komornicki, Z. Podgórski (red.), Idee i praktyczny uniwersalizm w geografii, Dokumentacja Geograficzna, 33, IGiPZ PAN, s. 129-133.

Komornicki T., 2008, Changes of car ownership and daily mobility in selected Polish cities, Geografický Časopis, 60, 4, s. 339-362.

Komornicki T., 2011, Przemiany mobilności codziennej Polaków na tle rozwoju motoryzacji, Prace Geograficzne, 227, IGiPZ PAN, Warszawa.

Kublik A., 2005, CEPIK częściowo nieświeży, Gazeta Wyborcza, wydanie z 29.11.2005, Dział Gospodarka, s. 30.

Kublik A., 2013a, CEPIK na CEBIT, Gazeta Wyborcza, wydanie z 7.03.2013, Dział Gospodarka, s. 21.

Kublik A., 2013b, Auta zombi w CEPiK, Gazeta Wyborcza, wydanie z 12.10.2013, Dział Gospodarka, s. 8.

Lansley G., 2016, Cars and socio-economics: understanding neighbourhood variations in car characteristics from administrative data, Regional Studies, Regional Science, 3, 1, s. 264-285.

Menes M., 2018, Rozwój motoryzacji indywidualnej w Polsce w latach 1990-2015, Przegląd Komunikacyjny, 73, s. 14-25.

Ministerstwo Cyfryzacji, 2018, Rozporzqdzenie Ministra Cyfryzacji z dnia 25 maja 2018 r. w sprawie katalogu danych gromadzonych w centralnej ewidencji pojazdów (Dz. U. z 2018 r. poz. 1049).

Pacholski A., 2018, W Warszawie niemal trzy razy więcej aut na 1000 mieszkańców niż w Nowym Jorku. Auta pożeraja polskie miasta, https://oko.press/w-zielonej-gorze-dwa- 
razy-wiecej-aut-na-1000-mieszkancow-niz-w-nowym-jorku-auta-pozeraja-polskie-miasta/ (30.08.2019).

Samcik M., 2005, Bezprawny CEPiK?, Gazeta Wyborcza, wydanie z 13.01.2005, Dział Kraj, s. 6.

Strategia rozwoju transportu do 2020 roku (z perspektywq do 2030 roku), 2013, Ministerstwo Transportu Budownictwa i Gospodarki Morskiej, https://www.gov.pl/documents/905843/1047987/ Strategia_Rozwoju_Transportu_do_2020_roku.pdf/ead3114a-aac7-3cdd-c71d-7f88267ce596 (30.08.2019).

Thiel C., Schmidt J., van Zyl A., Schmid E., 2014, Cost and well-to-wheel implications of the vehicle fleet $\mathrm{CO} 2$ emission regulation in the European Union, Transportation Research Part A: Policy and Practice, 63, s. 25-42.

Whelan G., 2007, Modelling car ownership in Great Britain, Transportation Research Part A: Policy and Practice, 41, 3, s. 205-219.

\section{Summary}

Reports from the European Commission (e.g. European Commission, 2018) show a relatively high level of motorisation in Poland (leaving the country ranked $6^{\text {th }}$ among EU Member States). The number of cars per 1000 inhabitants is higher here than in any other of the formerly-communist countries acceding to the EU in or after 2004. Unfortunately, however, this situation inter alia reflects twisted statistics on motorisation that do not therefore offer a full or proper reflection of the real situation on the Polish car market.

This article has devoted itself to the analysis of shortcomings characterising three groups of motorisation statistics relating to:

1. the cars known as "dead souls" (end-of-life vehicles) - whose numbers are overstated (by perhaps 6 million cars - or $26 \%$ of the entire total), given the retention on the register of those that have not been on the road for a long time,

2. "cars with a grille" - part of a Poland-specific phenomenon that results in understatement of numbers of cars and overstatement of numbers of goods vehicles (to the tune of perhaps 750,000), given people's efforts to ensure that personal cars are approved for registration as commercial vehicles,

3. company cars, given overstatement (equal to perhaps 1.5 million) of numbers of vehicles in cities due to the presence of leasing companies and large enterprises operating company cars.

The spatial distribution across the country of cars in the above-mentioned groups is very uneven and does much to influence spatial patterns relating to Poland's motorisation rate (s). Overall, motorisation is much overestimated in large cities (e.g. Warsaw, Poznań, Katowice and Wrocław), while being underestimated in rural areas (especially in SE Poland). A crucial achievement of our analysis involves correction of official European statistics in this regard. The discrepancies characterising the statistics have the clear spatial distribution presented in Fig. 6. In its last section, this article then attempts to determine the consequences of such twisting of the motorisation statistics where both geographical research and decision-making are concerned. 